\title{
The Mollusen of
}

Coorgian Bay

A, D, ROBERTSON

QL 
Digitized by the Internet Archive in 2008 with funding from Microsoft Corporation 

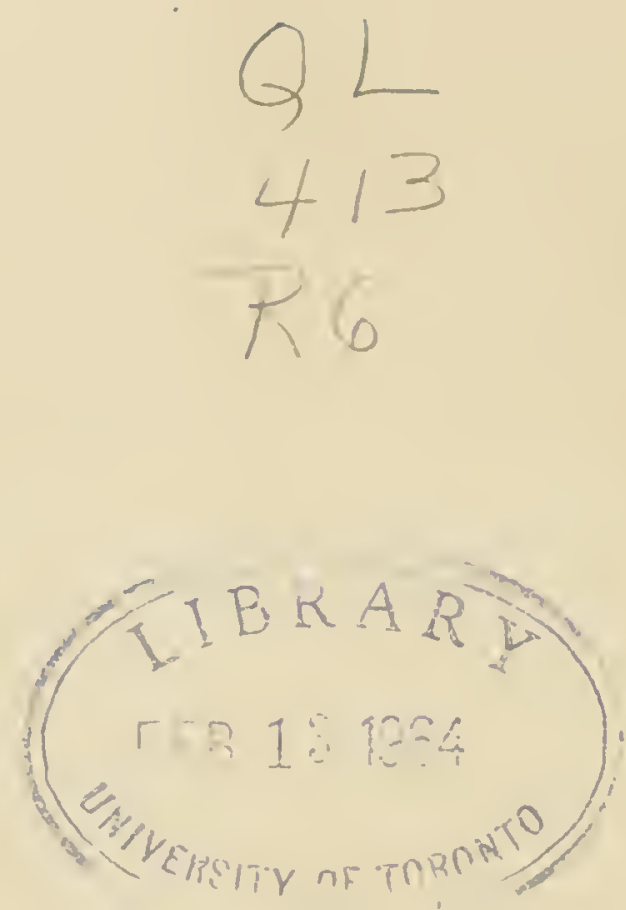

9.81454 
III.

\section{THE MOLLUSCA OF GEORGIAN BAY.}

\section{By A. D. Robertson, B.A., University of Toronto.}

$$
\text { (Plates } \mathrm{X}-\mathrm{XII} \text { ) }
$$

In 1910 the writer undertook, in connection with the work of the Biological Station, an analysis of the local molluscan fauna of Go Home Bay. This study has since been extended to include various points around Georgian Bay, but because of the labour involved in working over the material, this paper deals only with the more limited area, leaving the general distribution for future discussion. The analysis of the species is believed to be fairly complete, and special care has been taken to observe critically the specific characters and the variations, whether due to environment, age or other cause. Notice has also been taken of the food of the various forms and of the extent to which they themselves serve as food for fishes and other animals.

The collections along-shore were made by hand and hand-dredges, while in the deeper water use was made of an iron dredge, provided with a fine inner screen supported by a course outer screen. The latter method entails much labour in sorting over the material but gives excellent results.

In the identification of species the writer is indebted to Mr. Bryant Walker of Detroit and to Dr. H. A. Pilsbry and Mr. E. G. Vanatta of the Philadelphia Academy of Natural Science, who determined a number of species and confirmed the determination of others. He is also under obligation to Professor B. A. Bensley, Dr. E. M. Walker and Dr. A. G. Huntsman of the University of Toronto for much kind assistance and advice.

The environmental features of this region are of interest because it falls within the Archean area. A general account of these features is given elsewhere by Bensley ('14), but reference may be made to those which are more important from the standpoint of this paper.

1. The glaciated surface of the rock is sparingly and unevenly occupied by soil and bottom deposits, accumulating in basins and consisting chiefly of disintegrated particles of gneiss, often with high organic content.

2. The indented shore-line leaves projecting headlands of fully exposed and bare character, while the protected smaller bays form isolated swamps with usually a deep deposit of mud and much organic material.

3 The main shore gives place outwards to larger, then to smaller islands and finally to reefs and submerged shoals, with clear rock or boulder bottom.

4. The deeper waters of the larger bays and open waters have flat bottoms, consisting of mud of fairly high organic content alternating with exposed patches of the underlying rock. 


\section{$\$ 3 / 454$}

5. At places there are open or somewhat exposed channels with accumulations of clean sand, almost free from organic material.

6. In addition to the wave-action on the main shore and on the shoals, there is a constant flow of water in and out among the islands, giving conditions of exposure, temperature and oxygenation which are in marked contrast with those of the protected bays and especially with those of the inland ponds.

In general the species of mollusca exhibit great flexibility in their environmental relations. In many cases ecological selection is operative within broad limits, while in a few the environmental type is more or less specific. The chief factors in this selection appear to be (a) exposed or protected situation, (b) depth of water, (c) deglee of aeration, (d) character of the bottom, and (e) food conditions. In the Genus Lymnaca, the long-spired forms occur in the stagnant bays, while the short-spired ones inhabit rocky shores. The specics of Planorbis also occur in the swampy bays, though $P$. deflectus extends its lange to the exposed rocky islands and the pools occurring on them. Most of the species of Physa are quite general in their distribution, but $P$. integer prefer's the exposed shores. The genera Ancylus, Amnicola and Campeloma and the families Unionidae and Sphacriidae occur in swampy bays and also, though much less abundantly, in inland ponds, with an extension of this range in Amnicola, the Unionidae and sometimes Campeloma to the sandy channels and of the Sphaeriidae to these channels and to sand or gravel banks in the deeper water's. Goniobasis is found abundantly where there are currents of clear, well-aerated water, in sand channels, on sandy beaches and on the exposed rocky shores. The genus Valvata is a sand-loving one, although of the two species, one, tricarinata is also found plentifully in weedy., muddy bays.

The inland ponds are exposed to extremes of summer and winter temperature. They are limited in the facilities they afford for migration to the deeper waters. They are poorly provided with means of aeration and are often surfeited with decaying vegetation and so afford an environment not highly favorable to molluscan life. Few forms occur and these not abundantly. Among them are Ancylus parallelus, Campeloma decisum, Amnicola limosa and the Sphaeriidae.

The protected muddy bays where these conditions are reversed afford a rich molluscan fauna with a wide lange of species which includes the Unionidae, the Sphaeriidae, the genera Valvata, Amnicola, Goniobasis, Planorbis, Ancylus, Physa (with the exception of $P$. integer niagarensis) and the long-spired species of Lymnaea (palustris, columella and haldemani).

In the weedy sand-runs the same forms occur, with the exception of Planorbis exacuous, $P$. dilatatus and the Lymnaea mentioned above. In clean sand channels, free from weeds and exposed to currents, the Unionidae, the Sphaeriidae and the genera Campeloma, Valvata and Goniobasis occur.

The exposed rocky shores which seem to afford a scanty supply of food and an abundance of well-aerated water, yield Lymnaea emarginata canadensis, L. decollata, L. stagnalis sanctamariae, Planorbis deflectus and the various species of the Physa.

In the shallow island pools which are well-aerated and have a good supply of food, but which, on the other hand are subjected in some cases to destruction by drought and to severe winter conditions, Planorbis deflectus and Lymnaea. palustris abound. 
JESSIONAL PAPER No. 39b

In deep dredging from sandy or gravelly bottoms, the Sphaeriidae and the genus Valvata are obtained.

The total number of species identified is 37 , representing 14 genera in 8 families, as follows:-

I. Family lymnaeidae.

A. Genus Lymnaea.

1. Lymnaea stagnalis sanctamariae, Walker.

2. Lymnaea (Galba) decollata, Migheis.

3. Lymnaea (Galba) emarginata canadensis, Sowb.

4. Lymnaea (Galba) palustris, Muller.

5. Lymnaea (Pseudosuccinea) columella, Say.

6. Lymnaea (Acella) haldemani, (Deshayes) Binney.

B. Genus Planorbis.

7. Planorbis (Helisoma) bicarinatus, Say.

8. Planorbis (Pierosoma) trivolvis, Say.

9. Planorbis (Planorbella) campanulatus, Say.

10. Planorbis (Menetus) cxacuous, Say.

11. Planorbis, (Menetus) dilatatus, Gould.

12. Planorbis (Gyraulus) hirsutus, Gould.

13. Planorbis (Gyraulus) deflectus, Say'

II. Family PH YSIDAE.

C. Genus Physa.

14. Physa heterostropha, Say.

15. Physa ancillaria, Say.

15a. Physa ancillaria magnalacustris, Walker.

15b. Physa ancillaria vinosa, Gould.

16. Physa gyrina, Say.

17. Physa integer niagarensis, Lea.

D. Genus Ancylus.

18. Ancylus parallelus, Hald.

III. Family streptomatidae.

E. Genus Goniobasis.

19. Goniobasis livescens, Menke.

20. Goniobasis haldemani, Tryon.

IV. Family amnicolidae.

F. Genus Amnicola.

21. Amnicola limosa, Say.

22. A mnicola emarginata, Küster.

23. A mnicola lustrica, Say.

V. Family valvatidde.

G. Genus Valvata.

24. Valvata tricarinata, Say.

25. Valvata sincera, Say.

VI. Family viviparidae.

H. Genus Campeioma.

26. Campeloma decisum, Say. 
VII. Fimily UNIONIDAE.

I. Cicmus Lampsilis.

27. Lampsilis ventricosus, Barnes.

2S. Lampsilis lutcolis, Lamarck.

2S:. Lampsilis lutcolis rosaceus De Kay.

J. Genus Anodonta.

29. Anodonta grandis, Say.

29a. Anodonta grandis footiana, Lea.

I. Genus Anodontoides.

30. Anodontoides ferussacianus, Lea.

I. Geuns Unio.

31. Unio complanatus, Solander.

VIII. Family sphaERIIDAE.

M. Genus Sphaerium.

32. Shpaerium simile, Say.

33. Sphaerium striatinum, Prime.

34. Sphaerium rhomboideum, Say.

35. Sphaerium (Musculium) securis, Prime.

36. Sphacrium (Musculium) partumeium, Say.

N. Genus Pisidium.

37. Pisidium abditum, Hald.

Family LYMNAEIDAE.

Represented by 13 species of Lymnea and Planorbis, together forming the third of the total number of Molluscan species.

\section{Genus Lymnaea.}

Of six species identified, two, L. emarginata canadensis and L. Palustris are the prevailing types. Both occur abundantly. L. haldemani was taken in only two situations, although it was present in numbers $L$. decollata was taken in several places, but nowhere abundantly. Of $L$. stagnalis sanctaemariae only six specimens in all were obtained. L. columella was frequently found, but not in numbers.

L. stagnalis sanctaemariae, IValker. The six specimens were identified as this species and variety by Mr. E. G. Vanatta. The shortened spire corresponds to the exposed situation in bare rocky channels. A light colored, transparent shell, 5 to $5 \frac{1}{2}$ rounded whorls with distinct suture. The aperture is broadly ovate, the edge of the lip thin, flared anteriorly; slit-like umbilicus widely open or nearly closed by the callus. (Pl. XI, Fig. 1S).

L. (Galba) decollata, Mighels, occurs on rocky shores and in shallow rocky bays of outer islands. Stout, nicely formed little shell, rhomboidal in outline when viewed facing the aperture. Large body whorl, expanded aperture and short, sharp spire. Whorls 3 . Color brownish horn, tinged with green, apical whorls darker, white varical thickenings on body whorl. In comparison with L. emargi- 
nat canadensis the shell is smaller, shorter and smoother, the whorls fewer and more convex and the sutures are more impressed. (Pl. X, Fig. 7).

L. cmarginata canadensis. Sowb. ; very abundant on clean rocky shores, especially of the outel islands. Found also on sand and pebble bottom. Corresponding to its exposed position and in contrast to the other species, L. palustris, it is thickshelled with shortened spire and is of light coloration. It is a medium-sized species (adult length 20-25mm.) and is usually recognized easily by its light horn colour and malleated surface. The spire is shorter than the aperture, the whorls wellrounded, 5-6 and the sutures distinct. The aperture is large and ovate with a somewhat flaring lip and with reddish varical thickenings usually prominent immediately behind it. A white callus spreads over the body-whorl and covers but does not close the deep slit-like umbilicus. Usually with several whitish or reddish varical thickenings. Identified as this variety by Mr. E. G. Vanatta. As it occurs at Go Home it is quite variable, especially in surface malleation, thickness of the shell, height of the whorls and length of the spire. Thinner shells show more definite malleations. Its food consists of algæ. It has been taken from the stomach of the whitefish, Coregonus clupeiformis. (Pl. X, Fig. 14).

L. (Galba) palustris, Muller, abundant in shallow bays on the bottom or on submerged vegetation, often on mud flats above the water's edge. It prefers moderately high temperatures. It is easily recognized by its narrow elongated form, dark colour and by the aperture which is usually shorter than the spire. Lip somewhat flared. Surface of shell variable, smoother in island pools, usually roughened by coarse lines of growth in muddy bays. Sometimes malleated. Color brown to almost black, darker in pools, often whitish due to erosion. In young, color darker and lip not flared. Distinguishable from $L$. emarginata canadensis in the more slender elongated form, narrower and shorter aperture, longer spire, darker color and distinct habitat. It feeds upon the filamentous green algæ, diatoms and desmids. Found in the stomachs of whitefish. (Pl. X, Fig. 8).

L. (Pseudosuccinea) columella, Say. Common on lower surface of lily-leaves in stagnant, muddy bays. Easily recognized by its expanded and oblique body whorl, its long aperture, expanded anteriorly, rather sharp-pointed spire and its delicate shell-structure. Lines of growth prominent. Its elongated form and especially its delicate shell are adaptations to its protected habitat. Food consists of diatoms, desmids and other green algæ. (Pl. XI, Fig. 15).

L. (Acclla) haldemani (Deshayes) Binney: Found on the lower surface of lilyleaves in well-sheltered muddy bays in late summer. Observed in but two situations, both of which were removed from open water and were especially well-protected. Several specimens secured in eacl situation. Diligent search failed to reveal any during the early summer and nothing was found to indicate their habitat during this period. These observations agree in their main features with Kirkland's account as given by Baker ('11). Those secured were, however, considerably removed from deep water; none were observed in the approaches to the bays, neither were any secured in dredging. This is the most striking Lymnaea of the region. Its extremely slender form, long spire, oblique, flattened whorls, long narrow aperture, sharply angular at the posterior end and its thin transparent 
shell are unnistakable characters. The long spire and delicate shells are in conformity with its protected habitat. It varies in length of spire, conxevity of whorls and size and shape of the aperture and the axis is often considerably twisted. Its food consists of alga. (Pl. X, Fig. 4).

\section{Genus Planorbis.}

Seven species were identified. Of these, three, P. bicarinatus, $P$. trivolvis and $P$. campanulatus belonging to a large-shelled group inhabiting muddy bays, possess comparatively high, sinistral shells and certain common characters in respect of the reproductive organs which will be dealt with in a subsequent paper. The others belonging to a small-shelled group with a more varied habitat possess low, flattened, dextral shells and, as far as examined, certain other characters in the reproductive-organs. This group includes $P$. hirsutus, deflectus, exacuous and dilatus, the range of distribution of which varies with each species.

Planorbis bicarinatus, Say, occurs abundantly in weedy sand runs and weedy muddy bays; found also on rocks near the latter. Distinct and easily recognized by the two prominent angular carinae. Aperture slightly oblique, somewhat triangular, broadly rounded below, lip thin with varical thickening behind. Shell bi-concave, lower concavity with the sides interrupted by the carinae, upper smooth and funnel-like. Former apertures often evident on the body whorl as pronounced transverse ridges with darker periostracum. The possession of a broad high shell, which is carried on edge and has an aperture only slightly oblique, doubtless indicates for this form sheltered rather than exposed situations. In the young the carinae as pronounced but the aperture less oblique than in the adult. Food consists of green algæ. (Pl. X, Fig. 5).

Planorbis trivolvis, Say.; found plentifully in protected muddy bays and sometimes along the sheltered shores of the inner islands. Prefers shallow bays with comparatively high temperature. Found only in shore collections and water less than 2 feet in depth. The largest Planorbis of the region (Adult measurements,width 20-30 mm, length 10-13 mm). Shell with shallow concavity above the smooth slopes of which are interrupted by the carina of about the last half of the body whorl. A deep umbilicus into which the rounded whorls disappear below. Aperture large, triangular or rhomboidal in outline, narrower above, lip thin, much flared with a varical thickening behind. One or more former apertures evident. Lines of growth coarse. Not fitted for exposed situations because of the size and shape of the shell and the vertical position in which it is carried. Varies with age. Young lighter in color, shells high and narrow, while adults are much broader than high. Recognized easily at all stages by the upper concavity of the shell. Series shoming all stages readily secured. Eggs laid in flat brownish capsules on lily-leaves, sticks and even on other molluscs. Food, filamentous alg:e, diatoms and desmids. (Pl. X, Fig. 6).

Planorbis campanulatus, Say.; occurs abundantly in weedy places, both muddy and sandy, up to the depth of at least three fathoms. Easily recognized by the campanulate expansion of the body whorl a short distance behind the aperture and 
SESSIONAL PAPER No. 39b

the narrowly constricted throat just behind this. Aperture rhomboidal, narrowed above. Narrowly rounded tops of the whorls all in the same plane. Lower surface like trivolvis but narrow lower edge of the whorls more rounded and less angular. Lines of growth coarse, regular and parallel. Adapted in the same manner as the two preceding species to protected rather than exposed situations. Often distorted so that the tops of the whorls are inclined at various angles. Varies considerably in length of campanulate expansion and also in thickness of shell. Feeds on filamentous green algæe, diatoms and desmids. (Pl. X, Fig. 1).

Planorbis exacuous, Say.; occurs in protected weedy places, never in large numbers. A well-marked species, having as distinguishing features a very sharp peripheral carina, a lens-shaped shell and small size. Whorls flattened above, broadly rounded below. Aperture triangular and very oblique. The greatly flattened shell and very oblique aperture which allow it to lie close to the surface over which it crawls would seem to adapt it to an exposed habitat, yet it was found only in protected places. Varies in color, light coloured in sandy, and brown in muddy places. (Pl. X, Fig. 3).

Planorbis dilatatus, Gould, occurs on sticks along muddy river banks and in muddy bays. Only a few obtained. Small brownish; top of shell flat; sharp peripheral keel almost level with top of shell; whorls broadly rounded below; aperture oblique; compared with $P$. exacuous it is smaller and higher in proportion, the whorls are flatter above and much more convex below and the carina is placed much higher.

Planorbis hirsutus, Gould, occurs plentifully in weedy, sandy channels and in muddy bays or in channels on smooth rocks covered with light deposit of sediment. Easily recognized by the rough hairy shell. Shell wide and flat, having a sharp, strongly deflected peripheral keel and a very oblique aperture. Surface covered by crowded rows of hairs. Last portion of body whorl often strongly deflected. Shell varies greatly with age. A shell of about three and a half whorls is concave above and below, the aperture is only slightly oblique, the centrally-placed peripheral keel is just appearing behind the aperture, the shell is high and all the whorls are on the same level. In older shells the aperture becomes oblique, the shell becomes wide and flat, and there is a pronounced peripheral keel deflected downwards. The last whorls also drop below the level of the preceding whorls and the shell becomes saucer-shaped. (Pl. X, Fig. 2).

Planorbis deflectus, Say, the most abundant Planorbis species of the region, possesses a wider range of habitat than any other species, plentiful in quiet weedy bays, in weedy sand channels and in shallow dark-colored pools on islands. Occurs also on exposed shores. Recognized by its small size and rounded periphery. Aperture only slightly oblique. Color varies from yellowish on lily-leaves in bays to dark brown in dark island pools. Whorls in one plane or with last part of bodywhorl deflected downwards. Periphery sometimes flattened on its upper edge, giving a peculiar sloping aspect to last whorl. Some specimens banded alternate white and dark brown. 
Family linsidas.

Represented by six species belonging to two genera, Physa and Ancylus.

\section{Crenus Physa.}

Of this genus five species were obtained. Four of these are large and darkcolored, have short spires, thin shells and indistinct sutures and occur throughout a wide range of habitat. The fifth is small, light colored, with white varical thickenings of the whorls, has a more elongate spire and is found only on semi-cxposed rocks. Although the two groups are quite distinct, the species within the first group are not so clearly differentiated. The characters upon which the species of this genus are based are exceedingly variable and the extremes of variation grade into one another so smoothly that an attempt to verify the present classification by breeding experiments and anatomical investigation seems desirable. The writer intends to undertake the task in the near future. In the meantime the distinctions here used will be those of the literature of the genus.

Physa heterostropha, Say, occurs usually in protected situations in weedy bays or quiet rocky channels, rare. Surface smooth and shiny, without sculpture, the spire elevated and the sutures distinct. Food, diatoms, desmids and other algæ.

Physa ancillaria, Say, very abundant, almost everywhere in sheltered bays and along partially exposed shores. In the spring it may be seen collecting in vast numbers to the breeding-grounds in rocky channels and in the bays of rocky islands. Within a few days after copulation the eggs are laid in elongated capsules. A single individual may lay as many as five capsules containing in all 150-300 eggs. Spire short, sutures not so distinct as in $P$. heterostropha. Shell more robust than in that species. Surface smooth and shining, sculptured. Varies much in surface sculpture, height of spire, size and shape of aperture and number of digitations on mantle. Such malformations as forked tentacles and lobes arising from upper surfaces of foot were found. Food consists of diatoms, desmids and other green algæ. A number were found in whitefish stomachs. (Pl. XI, Fig. 19).

A variety, magnalacustris, Walker, with white lines on body whorl also occurs.

The variety vinosa occurs in sheltered bays and on partially exposed shores. Shell robust, spire short but sharp; whorls rounded and suture distinct.

Physa gyrina, Say. Not very abundant, found in sheltered bays. Differs from $P$. ancillaria in larger size, more elevated spire, more slender form and coarser surface sculpture.

Physa integer niagarensis, Lea; found on somewhat exposed rocky shores. much smaller than any of previous forms, shell much like a small reversed $L$. emarginata canadensis. Shell light horn with many white bands transverse to whorls. Shell heavy, spire elevated, apex sharp, sutures distinct and whorls rounded. Identified by Dr. Pilsbry. 


\section{Genus Ancylus.}

Ancylus is represented by a single species.

Ancylus parallelus, Hald.; very common in sheltered bays on under sides of lily leaves and on sticks. Shell flat, pyramidal; apex $\frac{1}{3}$ length of shell from posterior end, directed backwards and to the left; sides nearly parallel, shell narrower in front. (Pl. XI, Fig. 17).

\section{Family streptomatidae.}

Represented by two (?) species of the Genus Goniobasis.

\section{Genus Goniobasis.}

Goniobasis livescens, Menke. Obtained abundantly where there are currents, in sand runs or along rocky shores and on the rocky shoals near the outer islands. Occurs also but not plentifully in muddy bays. Spire long and tapering, apex usually eroded away, whorls 8-9, flat tened, suture not deeply impressed, distinct carina at lower edge of whorl. Aperture small and rhomboidal; prolonged anteriorly into a slight groove, closed by an operculum borne on upper side of foot. Unlike the long spired species of Lymnaea which inhabit sheltered situations, this form which is also long spired is well-adapted to exposed places because of its strong heavy shell. In contrast with the Lymnaea also, it, when detached, does not float on the water, but sinks at once into deeper water. A quite variable species. Varies in length and stoutness of spire, usually high and slender, often quite short and stout, color dark brown, shaded with green, light green or white. In young, carina well-marked; in adults, no carina on body whorls; in younger, color much darker. Feeds on diatoms and desmids. (Pl. XI, Fig. 16).

Goniobasis haldemani, Tryon; (not positively identified.) Occurred on shady beach along exposed shore. Few obtained. More slender and elongated, whorls more rounded than in livescens. No carina and the color white tinged with green.

\section{Family amnicolidae.}

Represented by three species, all belonging to the genus Amnicola.

\section{Genus Amnicola.}

Of the three species obtained here, A. limosa is the most abundant. All occur in weedy places either with mud or sand bottom. A.limosa is secured also on the rocky shores of even the outer islands and $A$. limosa and lustrica were obtained in deep dredgings. Operculate.

Amnicola limosa, Say; obtained on weeds in sand channels or muddy bays, on rocky shores and in dredging at 20 fathoms or more. Very abundant, tentacles lorg and constantly in motion. The jet-black eyes placed at outer bases of ten- 
tacles. Shell globose, whorls convex, apex usually rounded. Umbilicus small, aperture rounded. Shows considerable variation. Shell may be conic, spire elongated and apex sharp. The sutures vary in distinctness. Eggs laid in small triangular capsules on weeds, sticks, stones and even on the shells of other molluses. (Pl. X, Fig. 9).

Amnicola cmarginata, Say. Not numerous. Found with A. limosa. Distinguished from it by the truncated apex, the first whorl not rising above the second. Spire also more elongated than usual in A. limosa.

Amnicola lustrica, Say; not abundant. Occurs with other species of Amnicola; dredged in 20 fathoms or more of water. Compared with A. limosa, shell thinner, spire much more elevated, apex sharp, body whorl scarcely larger than the preceding one. (Pl. X, Fig. 10).

\section{Family valvatidae.}

Two species belonging to one genus occur.

\section{Genus Vaivała.}

Of the two species, one, V. tricarinata occurs abundantly. Operculate. The plume-like gills borne within the mantle-cavity.

Valvata tricarinata, Say., abundant in weedy places among islands on either sandy or muddy bottoms. Occurs on sandy bottoms even to depth of 20 fathoms. Prominent carinae, usually three. Umbilicus broad, open to apex. Whoris loosely appressed. Quite variable. One or all of the carinae may be lacking or indistinct. The order of their reduction appears to be peripheral, lower, upper. In sandy places malformations in which whorls do not touch preceding whorls occur, seen in early whorls, body whorl or intermediate ones. Found in whitefish stomachs. (PI. XI, Fig. 21).

Valvata sincera, Say. Found only in dredgings in sandy places. Occurs at depths of up to 20 fathoms. Not abundant. Compared with $V$. tricarinata there are no carinae and whorls are more rounded. There are distinct, sharp, elevated ridges, parallel to lines of growth. In the young these ridges are finer and more closely placed. Subject in sandy places to malformations similar to those occurring in V. tricarinata. Abundant in stomachs of whitefish. (Pl. XI, Fig. 22).

\section{Family VIVIPARIDAE.}

Represented by one species belonging to Genus Campeloma.

\section{Genus Campeloma.}

Operculate. As family name indicates young are produced alive.

Campeloma decisum, Say; occurs abundantly in sheltered bays with soft mud bottoms and in sand channels with decaying vegetable content. Congre- 
gates in decaying lily stems and on decaying logs. Recognized easily by large, heavy greenish shell, with short spire and eroded apex, its large, broad, brownish mottled foot and its long tapering tentacles. Color varied by narrow, irregularly placed dark bands crossing the whorls. In dark water it is often rusty brown. Young lighter in colour, lip of aperture thinner and shell has numerous fine lines parallel to whorls. All stages of development from young in the uterus to the adult form are easily obtained. Feeds on decaying vegetable matter. (Pl. XI, Fig. 20).

\section{Family unIONIDAE.}

Represented by seven species belonging to four genera.

\section{Genus Lampsilis.}

Two species of this genus are reported.

Lampsilis ventricosus, Barnes. The single specimen obtained some years ago was identified by Bryant Walker as L. ventricosus canadensis, Lea, conforms to descriptions of $L$. ventricosus and since Simpson (1900) includes canadensis in synonymy of ventricosis it is here designated by the latter name. Shell, thick; color yellowish, darker in front. Few faint broad radiations behind, lines of growth coarse, beaks eroded, hinge line straight, nacre white, cardinal teeth double in both valves, lateral teeth single in right valve, double in left.

Lampsilis luteolis, Lamarck. Very abundant on the slopes of deep pools in sandy channels and along sloping muddy shores. Shell much higher behind the beaks. Beak sculpture consisting of about 13 fine wavy concentric ridges. Color light or dark brown, usually with numerous, sometimes brilliant narrow green rays. Two cardinal teeth in each valve, lateral teeth double in left valve and single in the right, long, curved and lamelliform. Nacre white. Hinge line curved. Varies in periostracum which may be smooth and shining or coarsely wrinkled, in outline of shell, in color in prominence and number of rays and in cardinal teeth which are pyramidal or lamelliform. Females inflated posteriorly. Young narrower than adults. A form is common here which is large and heavily shelled, has a dark brown periostracum of ten with a greenish sheen towards the umbones and is coarsely and closely wrinkled at the margin of the gape. The variety rosaceus which has smooth reddish-brown periostracum and rosy nacre also occurs. (Pl. XII, Figs. 23, 26, 30).

\section{Genus Anodonta.}

Of this genus one species occurs.

Anodonta grandis, Say, occurs plentifully on steep slopes of sand banks in sandy channels, and also, but less abundantly in the soft mud of sheltered bays. Shell thin, smooth, inflated, hinge-teeth lacking, usually dull in colour. Beak sculpture, four or five concentric ridges with anterior and posterior loops. Varies greatly in color, sometimes dull and almost rayless; at times brilliant, with many green rays. Varies also in inflation of shell and in outline. Forms were found typical of footiana as well as other typical of grandis, s.s., but there were also many intermediates. (Pl. XII, Figs. 25, 28). 


\section{Genus Anodontoides.}

Represented by a single species.

Anodontoides ferussacianus, Lea. Plentiful in shallow sand channels and also in muddy places. Compared with $A$. grandis is smaller and much more elongated. Fine radiating sculpture at posterior of beak in addition to the five or six concentric doubly looped ridges. Color brown, tinged with green anteriorly and below and rusty brown posteriorly and above. (Pl. XII, Fig. 27).

\section{Genus Unio.}

Of this genus also only a single species occurs.

Unio complanatus, Solander. Very abundant in sand channels and along muddy or sandy shores of the inner islands or bays. Shells dark brown, no rays, beaks eroded, placed well forward, height behind beaks not greatly exceeding that in front, anterior end rounded, posterior tends to be angled. Ventral margin and hinge margin nearly straight, margin behind hinge curved. Teeth, both cardinal and lateral, single in right and double in left valve. Very variable, shells, narrow or broad, light or heavy; nacre white or purple. In old shells ventral margin tends to become emarginate. (PI. XII, Fig. 29).

\section{Family sPHAERIIDAE.}

There are of this family, in this region, six species belonging to the two genera, Sphaerium and Pisidium.

\section{Genera Sphaerium.}

Five of the six species mentioned above belong to this genus.

Sphaerium simile, Say, occurs abundantly, buried in the sand on the slopes of deep pools in sandy channels; occurs also in the mud of sheltered bays. The largest of the family in this district. Beaks nearer anterior end of shell, inflated, closely approximated, beaks marked with coarse lines, lines of growth heavy, regular. Color brown or yellow, often brown with yellow border. Hinge line curved. Hinge slight. Varies in color. Young usually yellow, adult usually dark. Young thin, adult somewhat inflated. (Pl. I, Fig. 11).

Sphaerium striatinum, Lamarck. Abundant in sand banks in channels and in mud in sheltered bays. Shell somewhat inequilateral, beaks full, separated, lines of growth coarse with finer lines between. Beak sculpture not uniform, numerous regular coarse lines, few coarse lines irregularly placed or beak smooth. Shell thin, nacre bluish white with purple bands or patches.

Sphaerium rhomboideum, Say. Sand banks and muddy bays. Shell equilateral. Umbones depressed, approximated, marked by fine lines, lines of growth rather fine, regular; anterior slightly truncated, posterior somewhat angled below. Dark brown, narrow yellow border around margin; nacre bluish white. (Pl. X, Fig. 12). 
SESSIONAL PAPER No. 39b

Sphacrium (1/usculium) securis, Prime. Abundant in sandy channels. Small, fragile, much higher in front of umbones which are centrally placed. Truncated behind, rounded in front, rhomboidal in outline, umbones calyculate and inflated, marked by fine concentric lines; lines of growth fine. Found in stomachs of whitefish. (Pl. X, Fig. 13).

Sphaerium (Musculium) partumeium, Say. Identified by Mr. E. G. Vanatta. Sand channels. Shell equilateral, oval in outline, large, truncated behind, color yellow, lines of growth fine.

\section{Genus Pisidium.}

One species of this genus occurs here.

Pisidium virginicum, Bourguignat. Abundant in sandy channels. Dark colored. Umbones elevated, placed posteriorly, shell heavy, brown or yellowish, truncated behind, triangular in front. Lines of growth coarse. Cardinal teeth single in right valve, inverted V-shaped; double in left; oblique, anterior narrow, posterior stout, inclined towards pyramidal. Laterals stout, double in right valve, single in left.

ARTIFICIAL KEY TO THE SPECIES IN THIS REPORT.

Since the recognition of these species is not an easy matter the following key based upon shell characters is given to facilitate their identification.

A. 1. Univalve, shell consisting of one valve.

B. 1. Non-operculate, no operculum borne on upper surface of foot and closing the aperture of shell when animal is retraced.

C. 1. Spire elevated and dextral, or flat.

Family Lymnaeidae.

D. 1. Spire elevated and dextral.

Genus Lymnaea.

E. 1. Spire elongated.

F. 1. Much elongated and slender, whorls very oblique, shell thin. Lymnaea haldemani.

F. 2. Elongated but stout; dark colored. Lymnaea palustris.

E. 2. Spire short.

F. 3. Thin-shelled, body whorl very large, whorls very oblique. Length of shell $15-18 \mathrm{~mm}$.

Lymnaea columella.

F. 4. Shell large, smooth; whorls 5; length of shell 25-30 mm. Lymnaea stagnalis sanctaemario.

F. 5. Shell medium sized, usually malleated; whorls 5 ; length of shell $20-25 \mathrm{~mm}$.

Lymnaea emarginata candensis.

F. 6- Shell small, smooth; whorls 3; length of shell 10-12 mm.

Lymnaea decollata. 
D. 2. Spire flat.

Genus Planorbis.

E. 3. Shell large, high and sinistral.

F. 7. With wide shell concavity above.

Planorbis trivolvis.

F. 8. With narrow decp concavity above, two carinx.

Planornis bicarinatus,

F. 9. With no concavity above. Expansion behind the aperture. Planorbis campanulatus.

E. 4. Shell small, depressed and dextral.

F. 10. Shell covered with bristles.

Planorbis hirsutus.

F. 11. No bristles on shell.

G. 1. Peripheral keel level with the top of shell. Planorbis dilatatus.

G. 2. Peripheral keel centrally placed. Shell lens-shaped. Planorbis exacuous.

G. 3. No peripheral keel.

Planorbis deflectus.

C. 2. Spire elevated and sinistral or shell not spiral.

Family pHysidae.

D. 2. Spire elevated and sinstral.

Genus Physa.

E. 5. Shell large.

F. 12. No sculpture on surface of shell. Physa heterostropha.

F. 13. Surface sculptured, spire short, suture not impressed. Physa ancillaria.

F. 14. Surface sculptured, spire more elevated, sutures impressed. Physa gyrina.

E. 6. Shell small, usually whitish.

Physa integer niagarensis.

D. 4. Shell not spiral.

Genus Ancylus.

Ancylus parallelus.

B. 2. Operculate, operculum borne on the upper surface of foot and closing the aperture of the shell when the animal is retracted.

C. 3. Spire very high, shell large, length 25-30 $\mathrm{mm}$ :

Family streptomatidae.

D. 5. Whorls towards apex not rounded.

Goniobasis livescens.

D. 6. Whorls towards apex more or less rounded.

Goniobasis haldemani.

C. 4. Spire low or only moderately high.

D. 7. Umbilicus narrow. 
SESSIONAL PAPER No. $39 \mathrm{~b}$

E. 7. Shell small, about $5 \mathrm{~mm}$. in length.

Family a.rNicOLIDAE.

F. 15. Shell globoid or low conic; apex rounded. Amnicola limosa.

F. 16. Shell low, conic, apex emarginate. Amnicola emarginata.

F. 17. Shell high conic, apex sharp. Amnicola lustrica.

E. 8. Shell large and heavy. Apex usually eroded. Family VIVIPARIDA.

Campeloma decisum.

D. 8. Umbilicus wide.

Family valvatidae.

E. 9. Whorls bearing three carinae.

Valvata tricarinata.

F. 10. Whorls without carinae.

Valvata sincera.

A. 2. Bivalve shell consisting of two valves, united by a dorsal hinge.

B. 3. Shell large, one set of cardinal teeth in each valve.

Family UNIONIDAE.

C. 5. Shell heavy, bearing hinge teeth.

D. 9. Height behind beaks not greatly in excess of that in front.

Genus Lampsilis.

E. 11. Rays numerous and narrow.

Lampsilis luteolis.

E. 12. Rays few and broad.

Lampsilis ventricosus.

C. 6. Shell light, no hinge teeth.

Genus Anodonta.

D. 11. Shell high, no radiating sculpture on posterior part of beak. Anodonta grandis.

D. 12. Shell low, elongated, radiating sculpture on posterior of beak. Anodontoides ferussacianus.

B. 4. Shell small, two sets of cardinal teeth in each valve.

Family SPHAERIDAE

C. 7. Not trigonal in outline.

Genus Sphaerium.

D. 13. Beak not calyculate.

E. 13. Lines of growth regular, coarse.

F. 19. Shell usually with definite narrow yellow border and rhombic outline.

Sphaerium rhomboideum.

F. 20. Shell without definite yèllow border and oval in outline. Sphaerium simile. 
5 GEORGE V., A. 1915

E. 14. Lines of growth not regular, coarse, with numerous fine between.

Sphaerium striatinum.

D. 14. Beaks calyculate.

E. 15. Rhomboidal in outline.

Sphaerium (Musculium) partumeium.

C. 8. Shell trigonal in outline

Genus Pisidium.

Pisidium virginicum.

\section{LIST OF ARTICLES CONSULTED IN THE DETERMINATION OF THE FOREGOING SPECIES.}

1898. Baker, F. C.-The Mollusca of the Chicago Arca. The Chicago Academy of Sciences, (Natural History Survey); Bulletin No. III, Pt. I. 1898.

1902. Baker, F. C.-The Mollusca of the Chicago Area, The Chicago A cademy of Sciences, (Natural History Survey); Bulletin No. III, Pt. II. 1902.

1911. BAKer, F. C.-The Lymnæidæ of North and Middle America. The Chicago Academy of Sciences: - Special Publication No. 3, 1911.

1865. Binney, W. G.-Land and Fresh-water Shells of North America, Pts. II and III. Smithsonian Miscellaneous Collcctions: $(143,144)$ vol. VII, 1867.

1870. Binney, W. G.-Report of the Invertebrata of Massachusetts (A. A. Gould, edited by Binney) Boston, 1870.

1901. Crandall, O. A.-The Amcrican Physæ, Nautilus, 1901.

1905. Dall, W. H.-Land and Fresh-water Mollusks. Harriman Alaska Expedition, vol. XIII, New York, 1905.

1882. LatchFord, F. R.-Notes on the Ottawa Unionidæ, Transactions Ottawa Field Naturalists' Club, No. 3, Ottawa, 1881-82.

1865. Prime, T.-Monograph of American Corbiculidæ. Smithsonian Miscellaneous Colleciturlo. (145) vol. VII, 1867.

1858. SAY, T.-The Complete Writings of Thos. Say on the Conchology of the United States. Edited by W. G. Binney, New York, 1858.

1900. Simpson, Chas. T.-Synopsis of the Naiades or Pearly Fresh-Water Mussels. Proceedings of the U.S. National Museum: vol. XXII, Washington, 1900.

1873. Tryon, G. W., JR.-Land and Fresh-water Shells of North America, Pt. IV, Smithsonian Miscellaneous Collections (253) vol. 16; Washington 1873. 


\section{EXPLANATION OF PLATES.}

PIATE $\mathrm{X}$.

1. Planorbis campanulatus, Say, $x 2 \frac{1}{2}$.

2. Planorbis hirsutus, Gould, $\mathbf{x} 3$.

3. Planorbis exacuous, Say, $\mathbf{x} 3$.

4. Lymnæa haldemani, (Deshayes) Binney, x3.

5. Planorbis bicarinatus, Say, $\mathrm{x} 2$.

6. Planorbis trivolvis, Say, $\mathbf{x} 1 \frac{1}{2}$.

7. Lymnæa decollata, Mighels, x3.

8. Lymnæa palustris, Muller, x2.

9. Amnicola limosa, Say, $x 1 \frac{1}{2}$.

10. Amnicola lustrica, Say, $x 1 \frac{1}{2}$.

11. Sphærium simile, Lamarck, $\mathbf{x} 1 \frac{1}{2}$.

12. Spliærium rhomboideum, Say, $\mathbf{x} 1 \frac{1}{2}$.

13. Sphærium (Musculium) securis, Prime, x3.

\section{PLATE XI.}

14. Lymnæa emarginata canadensis, Sowb, $\mathbf{x 2}$.

15. Lymnæa columella, Say, $\mathbf{x} 3$.

16. Goniobasis livescens, Menke, x2.

17. Ancylus parallelus, Hald, $\mathrm{x} 3$.

18. Lymnea stagnalis sanctaemariae, Walker, $\mathrm{x} 2$.

19. Physa ancillaria, Say, $\mathbf{x} 3 \frac{1}{2}$.

20. Campeloma decisum, Say, $\mathbf{x} 1 \frac{1}{4}$.

21. Valvata tricarinata, Say, $3 \frac{1}{2}$.

22. Valvata sincera, Say, $3 \frac{1}{2}$.

\section{PLATE XII.}

23. Lampsilis luteolis, Lamarck, $\mathbf{x}_{4}^{3}$.

24. Series, lamellar to pyramidal teeth in Lampsilis luteolis, Lamarck, $\mathbf{x} \frac{3}{4}$.

25. Anodonta grandis, Say, $\mathbf{x}_{\frac{3}{4}}$.

26. Lampilis luteolis, Lamarck, $\mathrm{x}$.

27. Anodontoides ferussacianus, Lea, $\mathrm{x}^{\frac{3}{4}}$.

28. Anodonta grandis, Say, $\mathbf{x}_{4}^{3}$.

29. Unio complanatus, Solander, $\mathbf{x}^{\frac{3}{4}}$.

30. Lampsilis luteolis, Lamarck, $\mathbf{x}_{\frac{3}{1}}^{3}$. 


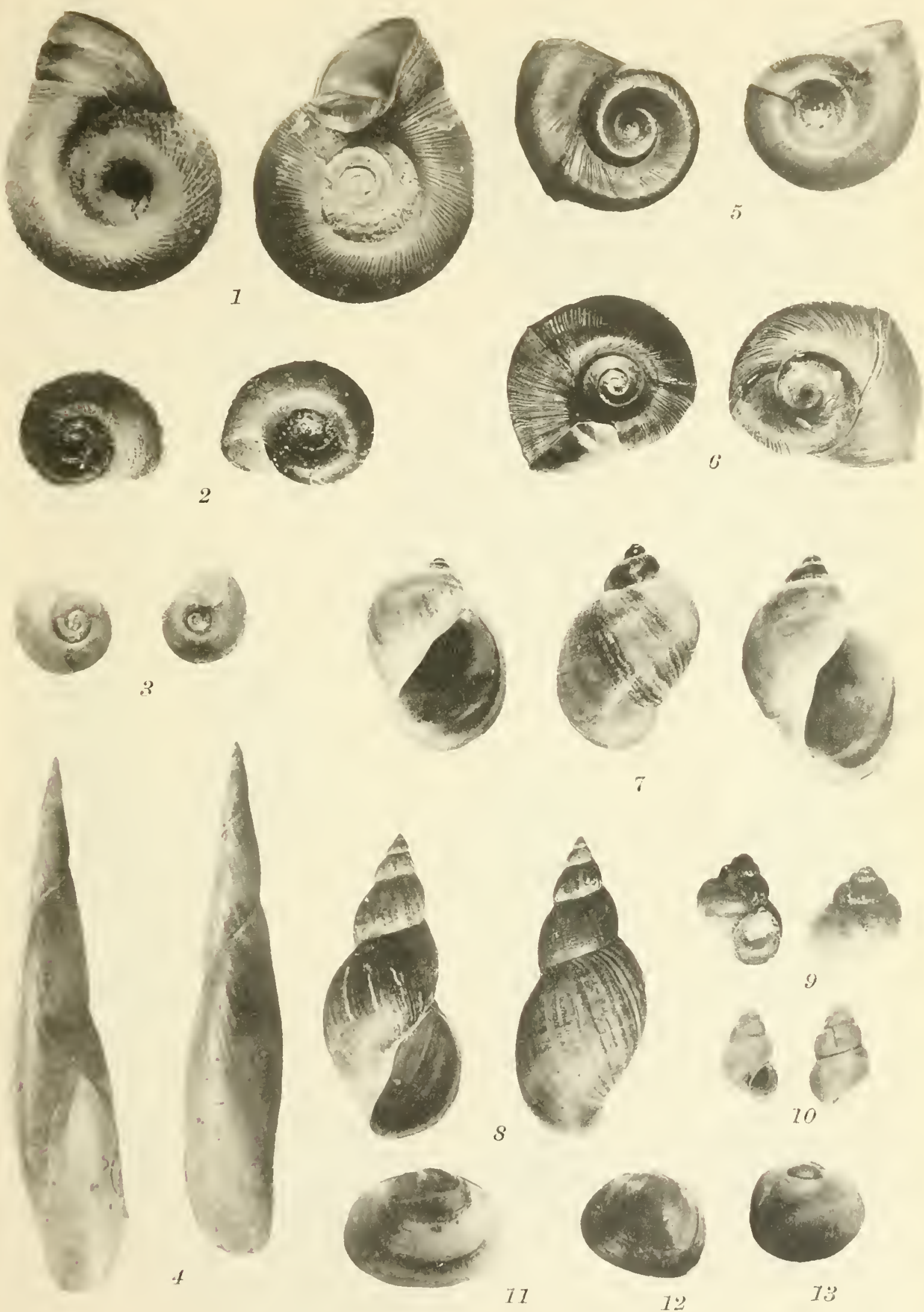



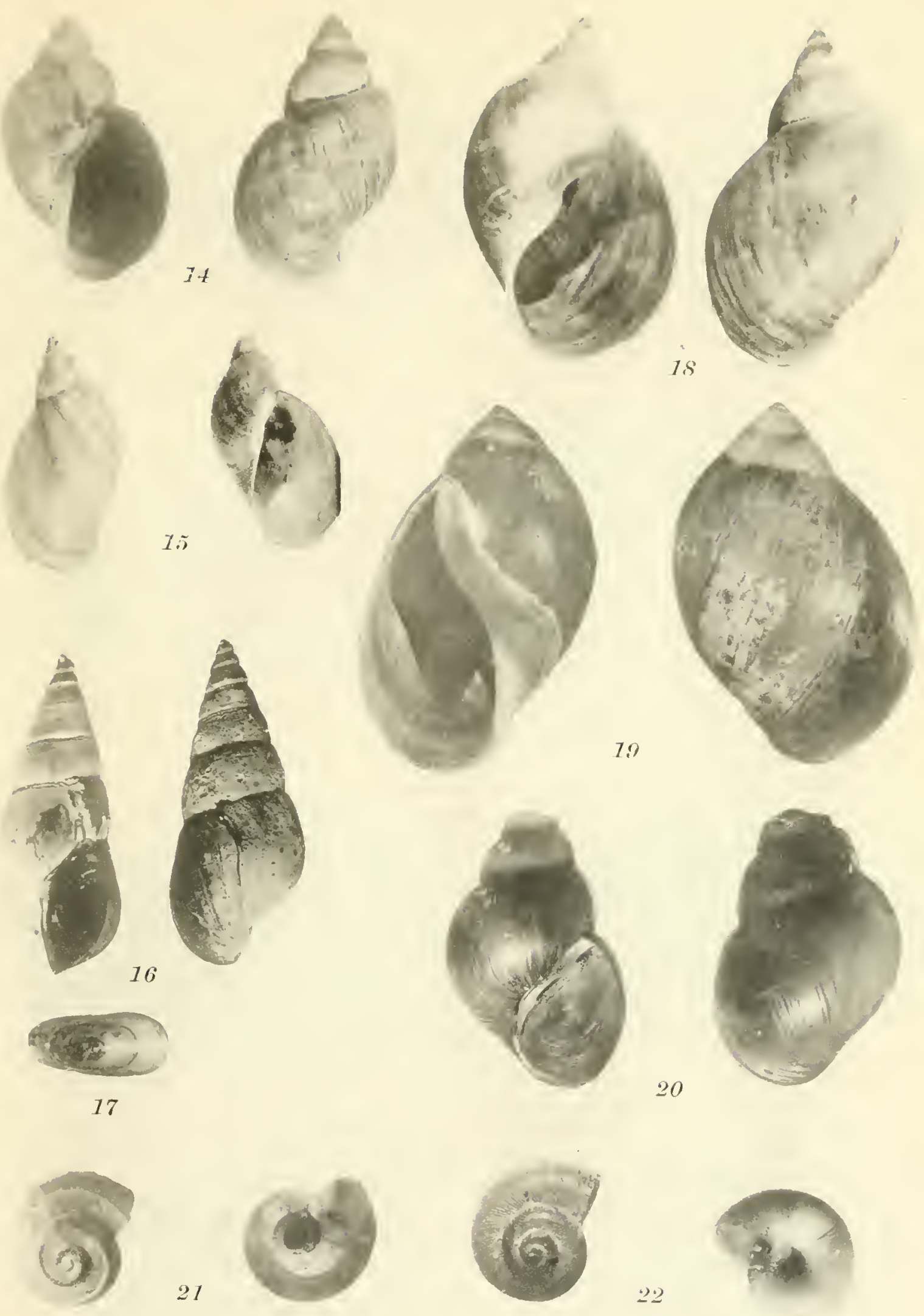





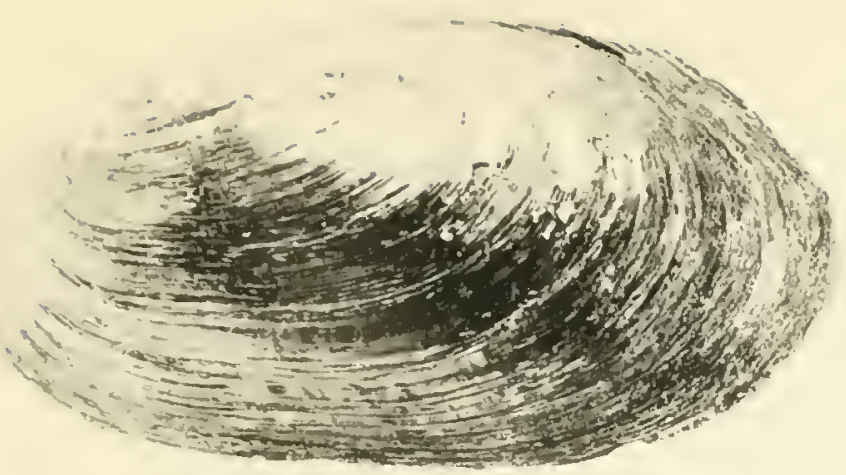

23

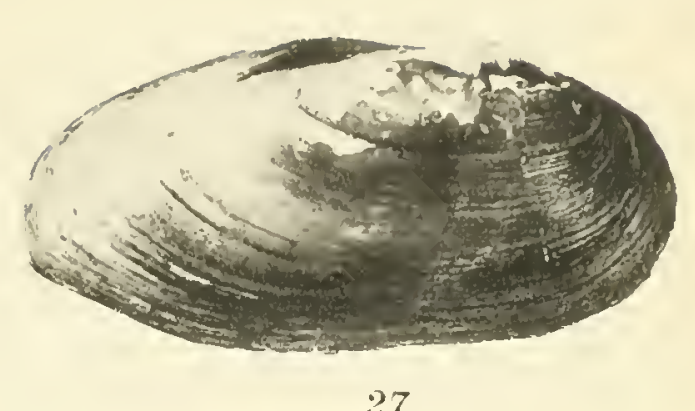

27

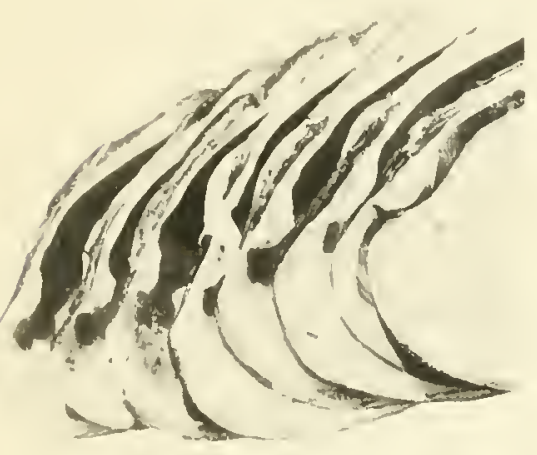

24

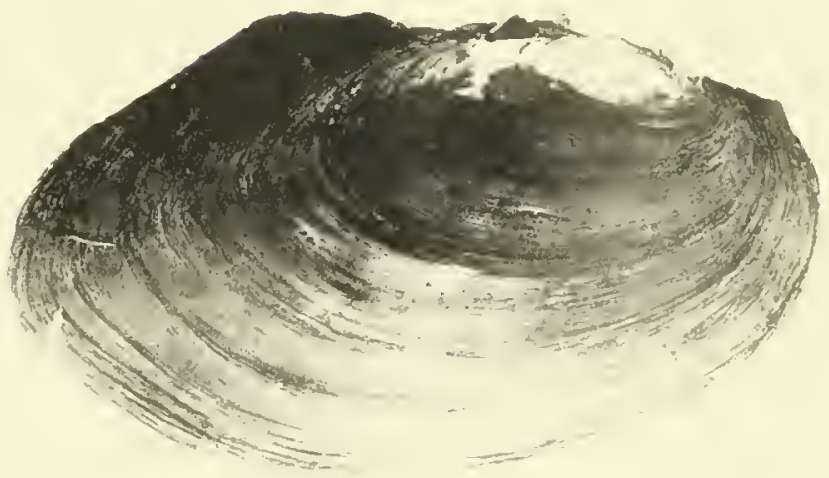

28

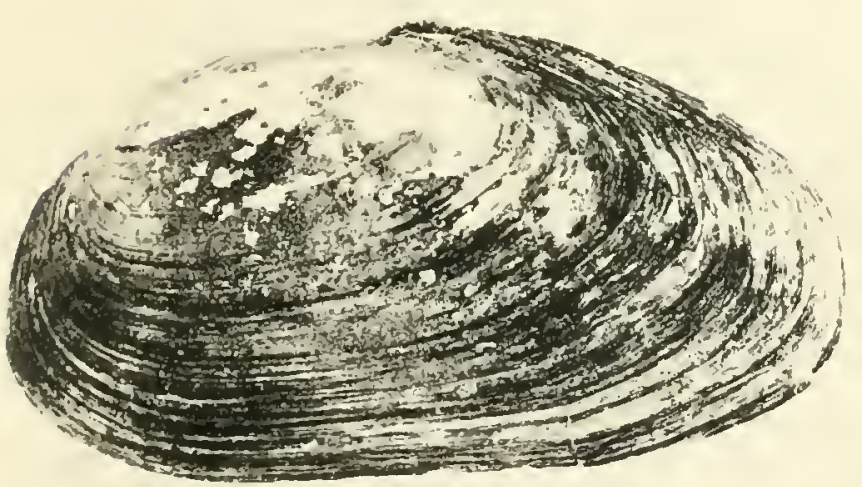

25

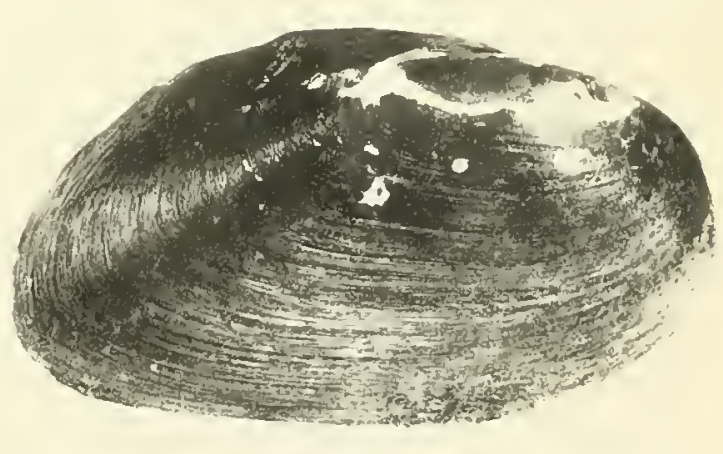

29

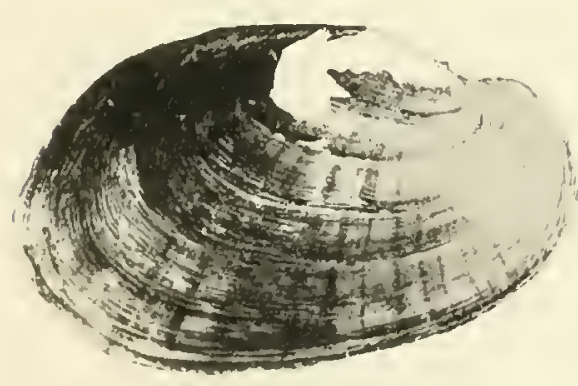

26

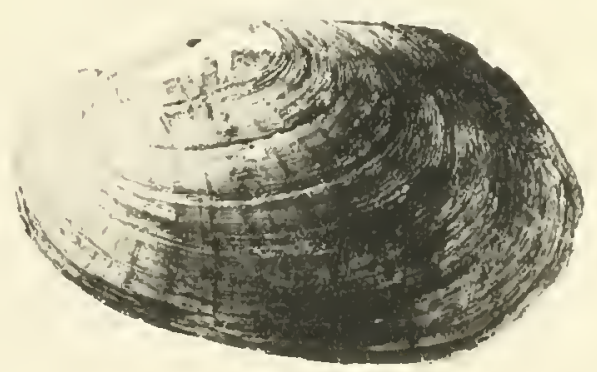

30 





\title{
BIOL. DEPT. UNIV. TORONTO,
}

QL

413

R6

Robertson, A

D

The mollusca of Georgian Bay

Biological

\& Medical

\author{
PLEASE DO NOT REMOVE \\ CARDS OR SLIPS FROM THIS POCKET
}

UNIVERSITY OF TORONTO LIBRARY 
